The use and...... Bhandari, Fine

\title{
THE USE AND ABUSE OF SOCIAL CAPITAL \\ IN SOCIAL SCIENCE
}

- Ravi BHANDARI

Ben FINE

\section{ABSTRACT}

In parallel with, and as complement to globalisation, social capital has enjoyed a meteoric rise in Sociology and across the social sciences in general over the last two decades. Not surprisingly, it has been particularly prominent across development studies, not least through heavy promotion by the World Bank. As a concept, though, as has been pointed out persistently by a minority critical literature, social capital is fundamentally flawed. Although capable of addressing almost anything designated as social, it has tended to neglect the state, class, power and conflict. As a buzzword, it has heavily constrained the currently progressive departure from the extremes of neo-liberalism and postmodernism at a time of aggressive assault by economics imperialism. Social capital should not be ignored but contested - and rejected.

KEY WORDS: Social Capital, Neoliberalism, Nepal, World Bank, Colonialism

The expectation of universality, however sincerely pursued, has not been fulfilled thus far in the historical development of the social sciences.... It is hardly surprising that the social sciences that were constructed in Europe and North America in the nineteenth century were Eurocentric. The European world of the time felt itself culturally triumphant.... Every universalism sets off responses to itself, and these responses are in some sense determined by the nature of the reigning universalism(s).... Submitting our theoretical premises to inspection for hidden unjustified a priori assumptions is a priority for the social sciences today.

---Immanuel Wallerstein from the Gulbenkian Commission, "Opening the Social Sciences," 1996

\section{INTRODUCTION}

Social capital as a concept rose to prominence during the 1990s, towards the latter half as far as development is concerned. Initially, 
social capital was used to reveal how family affects schooling; in the past decade it has come to explain why nations, regions, communities and individuals are rich and poor in every respect. While before then, it had scarcely warranted a mention, ${ }^{1}$ its leading proponent, Robert Putnam, was acknowledged in the 1990s to be the single most cited author across the social sciences. As a word, or two, social capital had certainly raised a buzz. What, how, and why is the subject of this contribution.

This article is written from a highly personal point of view; we were both heavily involved, if critically, with social capital from an early stage, one as a past World Bank economist and the other highly active in disseminating his views in a number of publications. We draw both on our professional and academic experiences, along with an anecdote or two that shed some light on the source and nature of buzzwording. Throughout, we assume at least a passing knowledge of what social capital is or is about although, as will become clear, it has far exceeded its initial popularisation as, 'It's not what you know, it's who you know that counts'?

In the next section, we offer a short account of the key features of social capital as it is has come to be deployed across the social sciences. This is followed by a discussion of its role within development studies and how it came to acquire it. The final section offers some more general commentary on social capital as yet another buzzword following the winds of intellectual fashion.

\section{SOCIAL CAPITAL IS AS SOCIAL CAPITAL DOES}

Our interest in social capital arose accidentally, although it was possibly an accident waiting to happen. In the mid-1990s, we had begun, although separately, to study the relationship between Economics and the other social sciences. We had become convinced, initially on casual but soon to be cumulative evidence, that economics imperialism (or colonisation of the subject matter of other social sciences) had entered a new, aggressive, wide-ranging and yet more palatable and successful phase. Consequently, we were understandably intrigued to find that two individuals at the opposite extremes of social science, Pierre Bourdieu and Gary Becker, were both using the term 'social capital': not least because Becker was and remains the leading practitioner of an economics imperialism of an older, longer-standing kind. Becker's 
The use and...... Bhandari, Fine

form of Economics treats all economic and social phenomena as if they could be reduced to optimising individuals interacting as far as possible as if a market were present. His so-called 'economic approach' to social science has obvious affinities to rational choice, differing only in subject matter (and knowledge of non-economic literature). ${ }^{3}$

From the simple question of how could the two Bs be deploying the same concept, one of us became embroiled in the meteoric rise of social capital across the social sciences, ultimately culminating in a book (Fine 2001). Since then we have limited ourselves to a watching brief, complemented by the occasional assault, ${ }^{4}$ with the intention of renewing at a later date to assess once more where social capital has got and where it is going. ${ }^{5}$ Our conclusions, and continuing perspective, on social capital have moved far beyond the two Bs conundrums. In retrospect, social capital has become a buzzword of intellectual fashion like so many concepts preceding it. As such, it has reflected both individual and collective degradation of scholarship. And it is this that needs to be addressed.

This is a powerful indictment. It can be justified by laying out the key features of social capital. First, collectively, users of the concept have developed a gargantuan appetite in terms of what it is, what it does, and how it is understood. Almost any form of social interaction has the potential to be understood as social capital. As a positive resource, it is presumed to have the capacity to facilitate almost any outcome in any walk of life, and to be liquid or fluid across them to a greater or lesser extent. And it is equally adaptable across subject matter, disciplines, methods, and techniques, at least within the social sciences. In short, in principle, and to a large if selective degree in practice, social capital can be anything you like.

Second, this imparts to users of the concept of social capital the property of being able to reinterpret all previous social science through its prism. Hence, social capital has been presumed to be a more general approach than that individually attached to notions such as networks, trust, linkages, and so on. Through its prism, though, these concepts and their lineage are bowdlerised. Social capital is equally at home as a residual or complementary category, explaining what was previously inexplicable in its absence. Thus, for example, social inclusion might be a form of social capital, it might be explained by social capital, or it might reinforce the effects of social capital (with social exclusion as the 
corresponding dark side). Inevitably, though, the social capital prism filters out more light than it lets through, in drawing simplistically upon basic categories of social analysis, entirely stripped of their rich traditions and contested meanings.

Third, social capital is an oxymoron. It presumes that there can be a capital that is not social. It is rarely made explicit what this asocial capital is, where the boundary lies between it and social capital, and what role is played by that other capital in itself and as complement to, or constraint upon, its alter ego. Social capital might be the counterpart to economic capital (asocial?), the state, or even personal capital. In what respect it is social and/or capital, and hence distinctive as such, is never explored.

Fourth, as a result, the economy, and economic theory, tends to remain unexamined in the context of social capital. There is some loosely formulated presumption that markets cannot work at all or cannot work perfectly in the absence of social capital. This opens the potential for (more) social capital to enhance the working of the market, just as it enriches non-economic behaviour and outcomes through collectivity.

Fifth, social capital offers a highly attractive analytical fix for Economics, as a residual theoretical and empirical factor. Differences in economic performance had traditionally been seen as the consequence of different quantities of capital and labour. The former had been refined to various types, such as physical, financial, environmental, and human capital. Social capital, for economists in their own very limited departure from neo-liberalism and theory of free markets, could be added to capture anything else that might contribute to performance, with the non-market such as social capital understood as the pathdependent response to market imperfections.

Sixth, despite its wide scope of definition in principle, social capital in practice has exhibited a number of no-go areas despite these being at the core of social interaction. Generalising over such an extensive literature is dangerous but omissions (apart from the economy other than as something given but to be enhanced), despite being significant elements in social interaction, include colonialism, imperialism, racism, class, the state, trade unions, and political parties and organisations. ${ }^{6}$ And, by the same token, cooperation and collectivity, for example, have been emphasised in numerous studies on Nepal (too many to list) 
The use and...... Bhandari, Fine

at the almost absolute expense of continuing economic-political-social colonialism, power and conflict.

Seventh, the policy perspective induced by uses of the concept of social capital, although never put in these terms, is self-help raised to the level of the collective. However good or bad things might be, they could be better if people interacted more, trusted one another, and cooperated. Social capital offers the golden opportunity of improving the status quo without challenging it. Everything from educational outcomes through crime prevention to better psychological health can be improved if neighbours and communities would only pull together and trust one another.

Eighth, Bourdieu is acknowledged to have been an early purveyor of social capital, and he placed considerable emphasis on both its class dimensions and its contextual content. He offered a much deeper understanding of social capital than what has followed, but also a narrower definition as he distinguished it from cultural and symbolic (and economic) capital. These differences have been lost in subsequent literature by rounding up the symbolic and the cultural into the social, whilst equally dropping the class and contextual content for universal notions of any collectivity across time, place and application. In place of Bourdieu, the rational choice or individualistic foundations of other renditions of the concept of social capital, drawing on the influence of the rational choice sociologist James Coleman, have come to the fore.? The most recent literature has begun to bring Bourdieu and context back in and to stand aloof from rational choice. Yet this renders the concept different in every application so that transposability between case studies and analytical categories relies upon a giant leap of faith. In this respect, social capital is treated as if it were capital in money form, along with presumptions of fluidity between its various components and effects (something for which Bourdieu himself was profoundly guilty).

Ninth, precisely because of its amorphous, all-encompassing nature, social capital is an ideal category, for want of a more tempered term, for the hack academic (Fine refers to this as "hackademia"). Apart from a focus for conferences and research grant applications, it has given rise to a typical article - "X and social capital." So, whatever has been done before can be done again with social capital serving as anything from organising theme to tangential by-line. In this respect, at least, there are 
parallels with the ubiquity of studies of "X and globalisation."

Tenth, purveyors of social capital have exhibited a capacity to absorb criticism by continuing to move forward. Opposition is readily perceived as seeking the addition of an otherwise missing variable or method so that the remedy is to incorporate what is otherwise absent. Where criticism is offensive to the core values of social capital, it is usually simply ignored, especially in relation to the points already elaborated. This is so much so that those contributions that do acknowledge criticism do so selectively for the purpose of supporting their own particular contributions!

Personally, we have found this so frustrating that we began to preface the frequent seminars and so on that I have given on social capital with the explicit challenge to the audience that they indicate where we are wrong or where there is disagreement. This has rarely, if ever, solicited a public response. But in private, individuals say they agree with us but were going to use social capital anyway as a means to further their own contributions that would, nonetheless, make correctives in the light of my criticisms. And, it would be claimed, at least economists are being civilised by bringing non-economic factors into their considerations. For the latter, though, the problem is less a matter of persuading economists to be civilised by continuing their colonisation of the other social sciences and more one of constituting an alternative Economics. In short, social capital has created a cordon sanitaire around itself through which criticism is ignored, incorporated, or even serves as a sort of repressive tolerance, legitimising the idea through acknowledging opposition. In place of the global, the economic, class, the state, conflict, gender, power and so on, social capital offers a bland alternative, highly conciliatory in principle and practice with more humanely presented forms of neo-liberalism and market fundamentalism, with token incorporation on narrower terms of other buzzwords such as empowerment and participation.

Eleventh, as should be apparent, irrespective of other criticisms, social capital has become definitionally chaotic as it is imbued with so many different variables, approaches, and applications. Again, this has frequently been acknowledged in the literature, only for another definition or approach to be adopted, compounding rather than resolving the collective conceptual chaos (the social capital of social capital!). There is a significant, if heavily outweighed, literature that is 
The use and...... Bhandari, Fine

critical of social capital and, almost certainly a body of social scientists who will have nothing to do with it because of its conceptual chaos and incoherence. Yet this aversion to social capital inhabits a parallel universe with limited dialogue with, or response from, the purveyors of social capital.

Last, social capital has thrived in the particular intellectual context peculiar to the $1990 \mathrm{~s}$ in which there has been a reaction against the extremes both of neo-liberalism and postmodernism. Like its counterpart, globalisation, but as its complement and opposite in many respects, purveyors of social capital have rejected the belief that markets work perfectly and have embraced the idea of getting real about how people go about their (daily) lives. The global, though, is notable for its absence from the world of social capital; it is more about communities accepting the world as it is and bettering themselves on this basis as a form of "participation," "empowerment," "ethnic identity" and "social responsibility." "Thus, and further, the "dark side" of social capital, as in corruption and community or racist violence for example, is often acknowledged only to be ignored. Even so, the World Bank use of social capital has tended not even to acknowledge criticism, but see below.

\section{SOCIAL CAPITAL AND DEVELOPMENT}

In view of the above, it is hardly surprising that development and social capital should be brought together. But the prominence of social capital within development has been considerably strengthened by its heavy promotion from an early stage by the World Bank. Why should this have been so?

In many respects, social capital offered, alongside other complementary buzzwords (e.g. participation, empowerment, identity politics, etc.), the dream concept for the challenges faced by the World Bank in the 1990s. The decade had brought a crisis of its (and the IMF's) legitimacy with mounting criticism of the neo-liberal/colonial policies attached to loans. The Comprehensive Development Framework (CDF) and PostWashington Consensus (PWC) were designed to restore that legitimacy (Fine et al. 2001, 2009). The rejection of the Washington Consensus at the rhetorical level was evident. This was even carried through in scholarship to some extent, even if not immediately, for example, in the case of privatisation. Yet it is arguable whether these shifts had any 
impact on policy itself, as an even wider range of market-supporting interventions than under the Washington Consensus became legitimised through a rationale of correcting market and non-market interventions.

These shifts also reflected changes underway within the discipline of Economics in general and Development Economics in particular (Jomo and Fine 2006, Bhandari 2007). The old 'informal', 'classical' Development Economics had long given way to the 'new', with its emphasis on mathematical techniques, econometrics, the virtues of the market, and the corresponding need not to distort it through rent-seeking, corruption and the like. But, in its reaction against neo-liberalism, mainstream Economics had begun to emphasise the importance of market imperfections and the need to correct them through non-market mechanisms. This has fed through into what has been termed the "newer' Development Economics, with the "PWC" to the fore.

In one major respect, the CDF and PWC exhibit a marked difference from earlier ideologies emanating from the World Bank. Although completely different, the Keynesian/welfarism/modernisation stance of the McNamara period and the neo-liberalism of the Washington Consensus had their own relatively simple message on how to achieve development. In contrast, the PWC emphasises that the incidence of market and non-market imperfections are uneven and contingent in form, extent, and consequences so that not one model fits all, and so on, and everything is micro. Social capital is at core the negative mirror image of rent-seeking, etc, with the same analytical framework but diametrically opposed conclusions - that non-market influences can be beneficial (rather than detrimental) to the market. As such, it incorporates the non-economic in a way that is consistent with the (non-)market imperfections approach and is sensitive in principle to difference from one application to another. I hasten to add that this does not necessarily make a policy difference; rather, it simply offers a richer scope in justifying policy. After all, there are limits to using neoliberalism as the rationale for substantial intervention.

In short, social capital continues to offer considerable leverage in the World Bank's dealings with the external world. In addition, it allowed for certain powerful internal institutional interests to be promoted, what Bhandari calls the "Colonial INGO-NGO-Agency-EmbassyGovernment Development Industrial Complex." The World Bank is 
The use and...... Bhandari, Fine

dominated by economists, numerically and intellectually, and of the worst type from the perspective of the social scientists (and mainly sociologists) under the shadow of the Washington Consensus. The $\mathrm{CDF}$ and PWC offered some opportunity for non-economists to be taken seriously. Social capital was strategically chosen as a judicious concept for that purpose. In a paper that is unusual for its information and honesty over the internal workings of the World Bank, Bebbington et al. (2004), all this is revealed, from Putnam's initial invitation to be involved through the attempts to engage (successful), but not to be dominated by (unsuccessful) the economists. Not surprisingly, this is not entirely the take of the paper's authors. Rather, they see themselves as the unrecognised, strategically compromising and so reviled, heroes of a hidden internal battle to civilise the World Bank's economists, and so bring the progressively social to the intellectual and policy practices of the World Bank, (see Fine 2007b) for a devastating response.

In this respect, for them, criticism of social capital has missed the point of its inner significance in shifting the Bank's thinking and hence policy. Of course, this leaves aside both the other influences on the thinking and practice of the World Bank and the broader impact of the promotion of social capital in development thinking and practice elsewhere. Essentially, at least in retrospective self-justification, these authors are asking us to devolve our intellectual responsibilities to them in order that they can promote their own positions within the World Bank around a concept that they themselves admit to be flawed. The parallels with the 'never mind the arguments just do it' stance on privatisation are striking. And they are ironic. For whatever the impact of the social capital on the design and implementation of particular World Bank projects, the strategy of the organisation in practice has been to shift as much of its finance as possible from the public to the private sector. This is so despite a World Bank rethink on privatisation adjudging it to have been previously too premature a gamble (Bayliss and Fine 2007).

Polemics aside, the account of Bebbington et al. (2004) is a striking illustration of how strategic thinking within the World Bank is forced, individually and institutionally, to conform to its shifting needs and practices, and how limited is the scope to buck its requirements. Such is the case on a grander scale for the resignations of Stiglitz, Kanbur and others. But where professional recruitment and careerism prove insufficient to serve the World Bank's scholarship, rhetoric, and policy, 
the delusion of internal influence and reform incorporates those who offer a little more by way of free thinking and altruistic motivation. This is not to say that the scholarship, rhetoric, and policy of the World Bank are pre-determined in and of themselves and in relation to one another. But they are embedded, to coin a phrase, in an institution and its practices that are heavily constrained and can be perverse in attaching intentions to outcomes. The reduction of the impact of social capital to the activities of a few scholars within the World Bank is at best partial and at worst misleading.

We were both, for other reasons, on to its importance for the World Bank from an early stage. I dredged through the Bank's dedicated website, http://worldbank.org/poverty/scapital, and witnessed firsthand its exaggerated importance as a way of circumventing the idea of the developmental state as an alternative to the Washington Consensus (Fine 1999b), although that the PWC would circumvent the developmental state proved correct. Interestingly, Fine's efforts did prompt a mole within the World Bank to contact him with three gems of wisdom in terms of the reaction he was likely to receive for his criticisms. First, he would be asked to back off as the World Bank was changing for the good. Second, none of his criticisms would be addressed. And, third, and not surprisingly he would be offered a job of sorts to internalise and incorporate criticism.

Sorry to say, even moles can get it wrong, and the last of these never materialised. Only on one occasion, the exception that proves the rule, has there been any serious attempt to engage in discussions. This was a seminar organised jointly by LSE and the ODI, specifically to provoke debate, and with Michael Woolcock as opponent. ${ }^{9}$ To my astonishment, he insisted as pre-condition for participation that I provide him with three questions to answer and he would reciprocate. I offered the following:

1. Discuss critically the relationship between social capital and globalisation.

2. Assess critically what is the social capital of the World Bank and other IFIs.

3. Discuss critically what social capital understands as, and adds to the understanding of, development, with what economic analyses it is consistent, and how it understands 'non-social', especially economic, capital, and capitalism. 
The use and...... Bhandari, Fine

These were indicative of a wish to explore the relationship between social capital and globalisation, economic development, and the practices of the World Bank itself. I do not have a record of Woolcock's questions but one was to ask what I would say to a South African nurse asking me how I would deal with HIV/AIDS, ${ }^{10}$ and another was why I did not publish in respectable journals. The latter is ironic in view of the knowledge Bank's total exclusion of Fine's notable and extensive work from its social capital website (including its extensive annotated bibliography) and from its overall website altogether (other than once for a legitimising exercise). ${ }^{11}$ In the event, while Fine did answer his questions, he totally ignored mine, preferring to offer a tangential discourse on some obscure management framework before departing to overview the implementation of the World Bank's social capital toolkit household survey for Albania. With social capital surveys having been widely adopted across developed and developing countries, whatever the intentions of the World Bank's social capitalists in moving internal dialogue and practice, the external impact has been considerable in this respect at least. ${ }^{12}$

\section{DECONSTRUCTING THE BUZZ}

In discussing consumer culture, I have argued that it can be characterised by six Cs (Fine 2002b and 2005). Whilst I hesitate to extrapolate from consumer culture to buzzwords, doing so does offer some insight. The first $\mathrm{C}$ is Constructed. Social capital has been constructed through a combination of academic and, to a much lesser extent, developmental practices that have mutually reinforced one another but to the exclusion of others, especially where critical or inconvenient (colonialism, class, state, power, etc).

Second, social capital is Contextual, like all concepts, in the more general sense of itself being a specific product of the material and intellectual circumstances that mark the turn of the millennium. This aspect of social capital is brought out by Putnam's foisting it, as an afterthought, upon his study of regional disparities in Italy from the twelfth century onwards. He then exports it to the twentieth-century USA as the way of understanding the decline of bowling clubs and the rise of television prior to finding an entrée into the World Bank. Today's context allows this to happen, and for social capital to be accepted and promoted as a legitimate and legitimised concept. It's the contemporary phlogiston of social theory. 
Third, social capital is Chaotic, not least in its multifarious uses and meanings. Far from this resulting in its dismissal from the intellectual arena, this appears to have promoted its use. It has been subject to hundreds of measures, or elements that make up a measure, so much so that it has been felt necessary to re-aggregate into intermediate categories such as linking, bonding, and bridging. These all mutually contradict one another across traditional social variables (such as class, gender, ethnicity etc.) quite apart from the conundrum of its perverse, dark or negative side (mafia and the like).

Fourth, social capital is Construed, that is it is not simply passively received as a well-defined and given concept but is reinterpreted and worked upon by those who engage with it. One aspect of that reworking, for example, has been to disassociate social capital both from Bourdieu (too radical) and from Coleman (too reactionary) unless one or other of these is the intent.

Fifth, social capital is the product of Contradictory pressures, as it seeks to accommodate both material and intellectual developments. How can the World Bank legitimise itself while pretty much continuing business as usual? How can the economy be ignored when we are deploying social capital? And how can we set aside class, power and conflict when we are addressing social capital?

Last, then, social capital is Contested or subject to conflict over its meaning. Among social capitalists themselves, this is resolved through chaotic compromise. Otherwise, contestation takes the form of exposing and rejecting social capital for its sore conceptual inadequacies and corresponding consequences for practice. Social capital has in part risen to prominence because it has been allowed to do so by those who have not engaged critically with it. By contrast, while globalisation has been shown to be equally flawed as a conceptual panacea, it has been universally addressed by its critics and won away, not only from neoliberalism but also from the intellectual "Third Wayism" characteristic of social capital.

The current (anti-) intellectual scene is marked by the demise within academia of the extremes of (attention to) neo-liberalism and postmodernism (interestingly, both frameworks are united in their assumptions in their glorification of the individual as a central unit of analysis and see the majority of the world population as inherently 
static, homogenous, and an obstacle to progress---no different that colonial discourse and ideology), ${ }^{13}$ and by the coincidental rise of economics imperialism in the form of market and non-market imperfections as universal explanandums. The consequence is that the content and dynamic within and between disciplines is extremely open, and to be determined by the integrity and values that scholars bring to their scholarship. Much the same applies to the more general influence of scholarship on development thinking and practice. In this light, the point is not so much to deplore the $6 \mathrm{Cs}$ and how they characterise social capital, as they must bear on any concept whether buzzword or not. Rather social capital has a content and dynamic that severely constrains progressive and objective developmental thinking. It must be more heavily contested, but through argued rejection, in terms of its own inner weaknesses as well as its strategic consequences irrespective of the odd individual or case study advantage that might appear to accrue. And its proliferation in countries in Nepal where hackacademia is unregulated and uncontrolled, there is an urgent need for less ideologically-driven research in the name of democracy and peace.

\section{ENDNOTES}

1 For debate over (absence of) history of social capital, see Fine (2007a) and Farr (2004 \& 2007). The latter's response, to the effect that there is a history, reports six million items for social capital on an internet search. Yet his own history is more or less forcibly confined to a single source, John Dewey, with a few other bit players.

2 Key texts include Harriss (2001), Smith and Kulynych (2002) and Bebbington, Woolcock, Guggenheim and Olson (2004). See also Fabio Sabatini's website http:/www.socialcapitalgateway.org/. For Fine's extensive expertise on the topic and for a more general context of economics imperialism, see http:/www.soas.ac.uk/departments/ departmentinfo.cfm?navid $=490$

3 On Becker and Bourdieu, see Fine (1999a). For fuller account of economics imperialism, see Fine and Milonakis (2007).

4 See Professor Bhandari's recent lecture online at Social Science Baha in Kathmandu, Nepal (Lecture XXIX, March 8, 2009) that reveals how new buzzwords of social capital, gender, empowerment, democracy, peace-building, ethnicity, and post-conflict studies (and postmodernism in general) is inherently incompatible with the field 
of development studies and is synonymous with age-old colonial ideology, despite its self-proclaimed progressive rhetoric.

$5 \quad$ See especially Fine (2002a \& 2003).

6 Although there is a healthy literature on social capital and political activity as such.

7 Note that Coleman as individual tends to be acknowledged more than his rational choice approach, explicit reference to which would deter many punters.

8 Moore (2001) for more general critique of incorporation of such notions in anaesthetised forms.

9 Given the excellent Woolcock (1998), it seems that mole's condition three is operative on occasion.

10 I cannot resist pointing to the answer that is given by a World Bank 'lead economist', Bonnel (2000, p. 849), who in discussing social capital, argues that, 'Reversing the spread of the HIV/AIDS epidemics and mitigating its impact':

\section{REQUIRE THREE SETS OF MEASURES:}

(i) Sound macroeconomic policies ...

(ii) Structural policy reforms ...

(iii) Modifying further the systems of incentives faced by individuals.

11 See foreword to Fine (2004).

12 Note, though, that Bebbington et al do at least reference (and essentially accept) my criticisms of social capital (other than strategically) but in the context of its having served its purpose within the Bank that can now, with its civilised economists, move on to issues of empowerment and the like. The mind boggles.

13 See Bhandari (2009) Lecture XXIX at Social Science Baha, March 8 for audio and discussion.

\section{REFERENCES}

Arestis, P. and M. Sawyer (eds..) (2004) The Rise of the Market, Camberley: Edward Elgar.

Bayliss, K. and B. Fine (eds.). (2007) Privatization and Alternative Public Sector Reform in Sub-Saharan Africa: Delivering on Electricity and Water, Basingstoke: Palgrave Macmillan, forthcoming.

Bebbington, A., S. Guggenheim, E. Olson and M. Woolcock. (2004) 
The use and...... Bhandari, Fine

'Grounding Discourse in Practice: Exploring Social Capital Debates at the World Bank', Journal of Development Studies 40(5): pp. 33-64.

Bhandari, Ravi. (2009). "Rising Ethno-Cultural Nationalism in Nepal: Postmodern Illusion or Democratic Delusion?" in Sociological Bulletin: Special Edition. Roots and Routes to Democracy in the Himalayas. Vol. 59 (1). (April-May). ISSN 0038-0229. (with Nanda Shrestha and Dev Raj Dahal).

(2009). Social Science Baha Lecture \# XXIX, March 8. www. soscbaha.org/content.php?page $=$ lecture $\% 20$ series

(2007). "The Peasant Betrayed: Towards a Human Ecology of Land Reform in Nepal". In Roy Allen's (ed.) Human Ecology Economics: A New Framework for Global Sustainability. Routledge Publishers. (Oct.)

- (2007). "The Significance of Social Distance in Sharecropping Efficiency: The Case of Rural Nepal." Journal of Economic Studies. Emerald Publishers. Vol. 34 (4). (Sept). pp. 290-310.

(2006). "Searching for a Weapon of Mass Production in Nepal: Can Market-Assisted Land Reform Live Up to its Promise?" in Journal of Developing Societies. Sage Publications. Vol. 22 (2). pp. 111-143. (June). www.jds.sagepub.com/archive.

Bonnel, R. (2000). 'HIV/AIDS and Economic Growth: A Global Perspective', South African Journal of Economics 68(5): pp. 820-855.

Farr, J. (2004). "Social Capital: A Conceptual History", in Political Theory, 32: pp. 6-33

Farr, J. (2007). 'In Search of Social Capital', in Political Theory, forthcoming.

Fine, B. (1999a). "From Becker to Bourdieu: Economics Confronts the Social Sciences", in International Papers in Political Economy 5(3): pp. 1-43, Reproduced with afterword in Arestis and Sawyer (eds.) (2004).

(1999b). "The Developmental State is Dead - Long Live Social Capital?", in Development and Change 30(1):1-19. 
(2001). Social Capital versus Social Theory: Political Economy and Social Science at the Turn of the Millennium, London: Routledge.

(2002a). "It ain't Social, it ain't Capital and it ain't Africa", Studia Africana No. 3:18-33.

-(2002b) The World of Consumption: The Material and Cultural Revisited, London: Routledge.

-(2002c). "They $\mathrm{F}^{* * \mathrm{~K}}$ You Up Those Social Capitalists", in Antipode 34(4): pp. 796-99.

(2003). "Social Capital: The World Bank's Fungible Friend", in Journal of Agrarian Change 3(4): pp. 586-603.

(2004). "Economics and Ethics: Amartya Sen as Point of Departure", ABCDE Conference, Oslo, 24-26 June, 2002, in The New School Economic Review 1(1), Fall, pp. 151-62.

(2005). "Addressing the Consumer", in Trentmann (ed.) (2005).

(2007a). "Eleven Hypotheses on the Conceptual History of Social Capital", in Political Theory, forthcoming.

(2007b). "Social Capital in Wonderland: the World Bank behind the Looking Glass", Mimeo Available from Author.

(2007). From Political Economy to Freakonomics: Method, the Social and the Historical in the Evolution of Economic Theory, London: Routledge, forthcoming.

Fine, B., C. Lapavitsas and J. Pincus. (eds.) (2001). Development Policy in the Twenty-First Century: Beyond the Post-Washington Consensus, London and New York: Routledge.

Frank, Andre Gunder. (1998). ReOrient. Berkeley: University of California Press.

Goldman, Michael. (2005). Imperial Nature: The World Bank and Struggles for Social Justice in the Age of Globalization. Yale: Yale University Press.

Harriss, J. (2001). Depoliticizing Development: The World Bank and Social 
The use and...... Bhandari, Fine

Capital, New Delhi: Leftword Books, revised edition, London: Anthem Press, 2002.

Jomo, K and B. Fine (eds.) The New Development Economics: After the Washington Consensus, Delhi and London: Tulika and Zed Press.

Moore, M. (2001). 'Empowerment at Last', in Journal of International Development 13(3): pp. 321-29.

O'Connor, J. (1973). The Fiscal Crisis of the State, New York: NY: St Martin's Press.

Oishi, T. (2001). The Unknown Marx: Reconstructing a Unified Perspective, London: Pluto Press.

Smith, S. and J. Kulynych. (2002). "It may be Social, But Why is it Capital? The Social Construction of Social Capital and the Politics of Language", in Politics and Society 30(1): pp. 149-186.

Trentmann, F. (ed.) (2005) The Making of the Consumer: Knowledge, Power and Identity in the Modern World, Berg: Oxford.

Woolcock, M. (1998) "Social Capital and Economic Development: Toward A Theoretical Synthesis and Policy Framework", in Theory and Society 27(2): pp. 151-208. 